\title{
The Impact of Nature Education on Turkish Students' Affective Tendencies towards the Environment and Scientific Curiosity
}

\author{
Gülbin Özkan ${ }^{1, *} \&$ Unsal Umdu Topsakal ${ }^{1}$ \\ ${ }^{1}$ Yildiz Technical University, Turkey \\ *Correspondence: Yildiz Technical University, Turkey. E-mail: gozkan@yildiz.edu.tr
}

Received: April 27, 2020

Accepted: May 22, 2020 Online Published: May 25, 2020

doi:10.5430/jct.v9n2p95

URL: https://doi.org/10.5430/jct.v9n2p95

This study was carried out within the scope of TUBITAK 4004 Nature Education and Science Schools Project: Plants in Every Area of Life II.

\begin{abstract}
The aim of this study is to investigate the impacts of nature education on the affective tendencies and science curiosities of students. In this study, one group pretest-posttest test design was used. The study group consists of 30 seventh grade students studying in Istanbul, Turkey. In the study, nature education implementations were carried out as 14 activities for five days. Some activities were held in university laboratories, some in trips, and out-of-school settings. The data of the study were collected by the Environment Affect Scale and Children's Science Curiosity Scale. The quantitative data collected were analyzed with the SPSS program. As a result of this study, it was found that the students' affective tendencies towards the environment improved significantly after the implementation. In addition, it was observed that students' scientific curiosity increased positively.
\end{abstract}

Keywords: nature education, affective tendency, scientific curiosity, environment, middle school students

\section{Introduction}

There are many lifelong learning environments where nature education can be taken. These environments are family, school, social environment, etc. Observations and experiments can be carried out personally, with particular opportunities for environmental education. There are also areas for examples forests, botanical gardens, trial-observation gardens, wetlands, parks, and arboretums. By opening plant samples under these institutions, it informs individuals about the characteristics of these creatures and provides environmental awareness (Şat, 2006). Turkey has an important place in the world in terms of flora and fauna, so it is important for individuals to gain environmental awareness.

Today, observing the undesired side effects of synthetic drugs used in the treatment of diseases brings the use of herbs in the field of health again. The plants people use for treatment are widely used all over the world, especially in Europe and America (Saya et al., 2000). Nearly 600 plant species used for treatment are grown in Turkey (Ozturk \& Ozcelik, 1991). It is important to use these plants correctly in order to prevent negative results. It is also possible to raise awareness of individuals about plants with nature education.

Nature Education is generally named with similar terms for example; place-based education, environmental education, outdoor education, and environment-based education (Louv, 2008). Nature Education differs from environmental education in one important point; nature education happens in a natural environment, while in environmental education the environment in which learning happens could be natural or constructed (Genc, Genc \& Rasgele, 2018).

The most important and main purpose of environmental education is the creation of environmentally literate individuals who are willing to protect the environment and who are aware of their responsibility in reducing environmental damage (Hungerford \& Tomera, 1977). Environmental literacy has four basic components; to perceive and interpret the relative health of environmental systems, to protect the health of these systems, to improve their health or to develop appropriate systems to improve these systems. (Disinger \& Roth, 1992). Affective 
tendencies towards the environment are the degree of the individual to take into account the structure of the society while making decisions about the environment and displaying responsible environmental behaviors as well as its sensitivity to the environment and environmental problems (Sontay, Gökdere, \& Usta, 2015).

Many factors affect learning in science education. One of them is a feeling of curiosity. Curiosity plays a key role in human cognitive, social, affective, spiritual and physical development, education, and scientific discovery, as it enables people to develop a broad set of knowledge, skills, and experience (Silvia, 2008). It is stated that a sense of curiosity is an important feature and an influential factor in people's learning process (Harty \& Beall, 1984). Curiosity in educational initiatives is seen as a skill that needs to be developed, supported, renewed, and nurtured (Driscoll, 2004). According to the literature, when students encounter an unexpected situation, suspicion, confusion, contradiction, cognitive conflict, innovation, complexity, conflict, uncertainty, lack of clarity and change, feelings of curiosity are triggered (Harty \& Beall, 1984). Scientific curiosity can be defined as the desire to understand and search for information about natural phenomena (Krapp \& Prenzel, 2011). The development of innate curiosity, teachers' understanding, protection, and support of an individual's scientific curiosity are among the aims of science education (Spektor-Levy, Baruch \& Mevarech, 2013). It is thought that students' scientific curiosity can be developed with the nature education carried out in this study.

There are many studies on outdoor education environments in the literature (Smith, Steel, \& Gidlow, 2010; Carrier, 2009; Fields, 2009; Guisasola, Morentin, \& Zuza, 2005). Studies on environmental education are also found in the literature (Oweini \& Houri, 2006; Makki, Bradley, Waliczek, \& Zajicek, 1999; Worsley \& Skrzypiec, 1998). These studies emphasized the role of environmental education. There are also studies examining environmental literacy at the middle school level (McBeth et al., 2008; Chu et al., 2006; Meuth, 2010). Studies investigating students' curiosity towards science have also been found in the literature (Harty \& Beall, 1984; Diaz, 2006; Serin, 2010). However, there has been limited study conducted about the effects of out-of-school lessons on scientific curiosity (Ting \& Siew, 2014). Ting and Siew (2014) studied the effects of out-of-school lessons on five grade students' scientific curiosity and found that out of school learning environments significantly improve students' scientific curiosity. This study focuses on seven grade students.

The research questions identified are as follows:

1. Does nature education have a significant effect on 7th-grade students' affective tendencies towards the environment?

2. Does nature education have a significant effect on 7th-grade students' scientific curiosity?

\section{Method}

\subsection{Design of the Research}

A one group pretest-posttest test design was used. In this design, the effect of the independent variable on the process was tested with a single group study (Büyüköztürk, 2004). The Environment Affect Scale and Children's Science Curiosity Scale were applied to the participants as pre-test and post-test. Before and after the nature education, an evaluation was made whether there was a difference in the affective tendencies towards the environment of the students and their scientific curiosity. The study was carried out in the fall semester of the 2018-2019 academic year. The application lasted a total of five days. A six-hour program was implemented daily. This study was carried out within the scope of the Tubitak Nature Education and Science Schools Project.

\subsection{Participants}

The district from which the sample was selected was randomly assigned. The sample consisted of 7 th-grade students attending 5 different middle schools in Istanbul, Turkey. Six students with limited opportunities from each school were identified by the school administration. In total, the research group consists of 30 students. Istanbul was choosen because of the rich and diverse vegetation that exits in this city.

\subsection{Data Collection Tools}

The Environment Affect Scale was developed by Sontay, Gökdere, and Usta (2015) to evaluate students' affective tendencies towards the environment. The scale consists of 15 items and has a five-point Likert type. It consists of three sub-dimensions: environmental responsibility, environmental sensitivity, and environmental perception. The Cronbach alpha coefficient of the scale was determined as 0.86 .

Children's Science Curiosity Scale was developed by Harty and Beall (1984). Adaptation to Turkish was done by 
Serin (2010). Sub-dimensions of the scale are novelty, lack of clarity, complexity of stimuli, and surprise/bafflement. Cronbach alpha reliability coefficient of the Turkish version of the scale was calculated as 0.87 . The scale is a five-point Likert type and consists of 30 items.

The scales were applied as pre-test and post-test before and after the application.

\subsection{Procedure}

Some activities were carried out in an open area, such as botanical gardens, some were carried out in an indoor area, such as a laboratory. During the implementation, which is Turkey's first garden of medicinal plant garden and the botanical gardens trips are arranged. During these trips, in addition to the students observing the plants in their environment, they participated in various activities. In these activities, different usage areas of plants were explained. In addition, ethnobotanical collections and herbarium collections were seen. In addition to the trips, different experiments were made in the laboratory. Different teaching techniques such as computer-aided visual education and games were used in the activities to ensure the active participation of students.

In this study, fourteen nature education activities were developed to develop the students' environmental senses and their curiosity towards science. Each activity was given by experts in the field and there purpose were to; explore the morphological features of plants, learn the use of plants, see the ethnobotanical collection, understand the use of plants for health, make paper, become a gardener, understand the medical properties of plants and gain environmental awareness.

The tools and equipment used in the events are easily found and applicable. During the implementation of the activities, active participation was made by including discussions. Attention has been paid to ensure that each event is held in the most appropriate environment. Some activities were held in university laboratories, while some were held in excursions and out-of-school settings. The activities are selected so that students can work interactively and can be listed as follows: biology laboratory, faculty of pharmacy campus garden 1, campus garden 2, herbarium, medical plants garden, botanical garden, faculty of art and design and faculty of education.

\subsection{Data Analysis}

The data were analyzed with the SPSS program to determine whether the students' change in their affective tendencies towards the environment and their scientific curiosity was significant before and after the application. T-Test was chosen for analysis since the distribution of the data met the assumptions for normality.

\section{Findings}

\subsection{Results from the Environment Affect Scale}

After determining that the distribution of the data provided the normality assumption, paired sample T-Test was chosen in the analysis of the data. Table 1 gives the T-Test results.

Table 1. T-Test Results of the Environment Affect Scale Mean Scores

\begin{tabular}{lllllll}
\hline & $\mathrm{N}$ & Mean & $\mathrm{S}$ & $\mathrm{sd}$ & $\mathrm{t}$ & $\mathrm{p}$ \\
\hline Pre-test & 30 & 45.20 & 5.83 & 29 & 5.05 & 0.00 \\
Post-test & 30 & 60.12 & 6.25 & & & \\
\hline
\end{tabular}

* Significant at $\mathrm{p}<.05$ level.

Table 1 indicates that nature education has a positive effect on the students' affective tendencies towards the environment scores.

Table 2 gives the results of the T-Test of the scores of the Environment Affect Scale sub-dimensions. 
Table 2. T-Test Results of the Scores of the Environment Affect Scale Sub-dimensions

\begin{tabular}{|c|c|c|c|c|c|c|}
\hline \multicolumn{7}{|c|}{ environmental responsibility } \\
\hline & $\mathrm{N}$ & Mean & $\mathrm{S}$ & sd & $\mathrm{t}$ & $\mathrm{p}$ \\
\hline Pre-test & 30 & 15.22 & 4.51 & 29 & 4.39 & $0.00 *$ \\
\hline Post-test & 30 & 19.79 & 5.87 & & & \\
\hline \multicolumn{7}{|c|}{ environmental sensitivity } \\
\hline & $\mathrm{N}$ & Mean & $\mathrm{S}$ & sd & $\mathrm{t}$ & $\mathrm{p}$ \\
\hline Pre-test & 30 & 13.20 & 5.15 & 29 & 3.02 & $0.00 *$ \\
\hline Post-test & 30 & 20.15 & 4.71 & & & \\
\hline \multicolumn{7}{|c|}{ environmental perception } \\
\hline & $\mathrm{N}$ & Mean & $\mathrm{S}$ & $\mathrm{sd}$ & $\mathrm{t}$ & $\mathrm{p}$ \\
\hline Pre-test & 30 & 16.78 & 5.15 & 29 & 4.02 & $0.00 *$ \\
\hline Post-test & 30 & 20.18 & 5.71 & & & \\
\hline
\end{tabular}

* Significant at $\mathrm{p}<.05$ level.

Considering the affective tendencies of the students towards the environment, it was concluded that there were significant differences from before to after the implementation for all sub-dimensions.

\subsection{Results from the Children's Science Curiosity Scale}

After determining that the distribution of the data provided the normality assumption, paired sample T-Test was chosen in the analysis of the data. Table 3 gives the T-Test results.

Table 3. T-Test Results of the Children's Science Curiosity Scale Mean Scores

\begin{tabular}{lllllll}
\hline & $\mathrm{N}$ & Mean & $\mathrm{S}$ & $\mathrm{sd}$ & $\mathrm{t}$ & $\mathrm{p}$ \\
\hline Pre-test & 30 & 96.69 & 6.88 & 29 & 19.02 & $0.00^{*}$ \\
Post-test & 30 & 118.25 & 6.60 & & & \\
\hline
\end{tabular}

* Significant at $\mathrm{p}<.05$ level.

As seen in Table 3, nature education has a positive effect on students' curiosity towards science.

Table 4 demonstrates the results of the T-Test of the scores of the scientific curiosity scale sub-dimensions. 
Table 4. T-Test Results of the Scores of the Children's Science Curiosity Scale Sub-dimensions

\begin{tabular}{|c|c|c|c|c|c|c|}
\hline \multicolumn{7}{|c|}{ Novelty } \\
\hline & $\mathrm{N}$ & Mean & $\mathrm{S}$ & sd & $\mathrm{t}$ & $\mathrm{p}$ \\
\hline Pre-test & 30 & 35.42 & 6.52 & 29 & 3.39 & $0.00^{*}$ \\
\hline Post-test & 30 & 38.59 & 6.87 & & & \\
\hline \multicolumn{7}{|c|}{ Lack of Clarity } \\
\hline & $\mathrm{N}$ & Mean & $\mathrm{S}$ & sd & $\mathrm{t}$ & $\mathrm{p}$ \\
\hline Pre-test & 30 & 29.20 & 6.65 & 29 & 1.02 & $0.00^{*}$ \\
\hline Post-test & 30 & 35.18 & 6.78 & & & \\
\hline \multicolumn{7}{|c|}{ Complexity of Stimuli } \\
\hline & $\mathrm{N}$ & Mean & $\mathrm{S}$ & $\mathrm{sd}$ & $\mathrm{t}$ & $\mathrm{p}$ \\
\hline Pre-test & 30 & 26.78 & 5.12 & 29 & 9.02 & $0.00^{*}$ \\
\hline Post-test & 30 & 32.18 & 6.71 & & & \\
\hline \multicolumn{7}{|c|}{ Surprise/Bafflement } \\
\hline & $\mathrm{N}$ & Mean & $\mathrm{S}$ & $\mathrm{sd}$ & $\mathrm{t}$ & $\mathrm{p}$ \\
\hline Pre-test & 30 & 5.29 & 2.34 & 29 & 5.02 & $0.00^{*}$ \\
\hline Post-test & 30 & 12.30 & 2.24 & & & \\
\hline
\end{tabular}

* Significant at $\mathrm{p}<.05$ level.

It was observed that there were significant differences between pre-test results and post-test results from before to after application for all sub-dimensions of scientific curiosity.

\section{Discussion and Conclusions}

As a result of this study, it was found that the students' affective tendencies towards the environment improved positively after the implementation. In addition, it was observed that their curiosity towards science increased positively. Based on the results of this study, it can be said that nature education affects the affective tendencies of the seventh-grade students and their curiosity towards science.

In this study, in which nature education is implemented, students' concretization with nature observations and experiments and performing activities may be a reason affecting their affective tendencies. This finding is consistent with the findings of the research by Erickson (2008) who concluded that natural outdoor spaces foster children the ability to explore and desire to know. Ting and Siew (2014) also found similar results. From the same perspective, Little and Wyver (2008) stated that learning through the environment can convince children's natural curiosity and desire for novelty.

Genc, Genc, and Rasgele (2018) found that an 11-day nature-based program that they implemented developed the affective tendency of seventh-grade students. Dinçol Özgür and Yılmaz (2013) found a positive increase in the affective tendencies of teacher candidates towards the environment as a result of the implementation in their nature education study with prospective teachers.

Patrick and Tunnicliffe (2011) stated that students could not learn plant-related information directly from the school. For this reason, it can be said that students' perceptions of the environment and their perception of nature and their curiosity towards science may change with the experiences they will acquire with their out-of-school learning activities related to plants, such as touching plants. It is expected that students' knowledge of learning by doing and living will ensure the permanence of the acquired features.

Poortinga, Steg and Vlek (2004) indicated that people's perceptions of emotional tendencies towards the environment as well as their knowledge and attitudes are effective. Therefore, it is necessary to attach importance to nature education both in and out of school.

When studies that examine the relationship between students' curiosity towards science and their academic success, it 
is reported that there are positive significant relationships (e.g., Harty \& Beall, 1984; Harty, Beall, \& Scharmann, 1985). Based on the positive relationship stated in the literature between curiosity towards science and academic achievement, it can be said that enabling students' curiosity feelings in science lessons will be an alternative way to increase their academic success.

\section{Suggestions}

Based on the findings of this study, it enables educators with an additional teaching and learning tecniques that can assist teaching. This study will ensure a perspective for educators to teach students through interesting and meaningful nature education activities. Teachers should instill students with the care of environment through nature trips and classroom activities. The number of laboratory studies should be increased. Students should be given the opportunity to get to know nature freely.

The implementation is done only with seventh grade students is a limitation of this research. Similar practices can be implemented at other levels of education. Another limitation is that it only takes place with these fourteen events. Similar to these activities, out-of-school learning activities and excursions can be planned by educators. Also, the absence of a control group in this research is another limitation. A similar study can be carried out in two groups.

\section{References}

Büyüköztürk, Ş. (2004). Veri analizi el kitabı. Ankara.

Carrier, S. J. (2009). The effects of outdoor science lessons with elementary school students on preservice teachers' self-efficacy. Journal of Elementary Science Education, 21(2), 35-48. https://doi.org/10.1007/bf03173683

Chu, H. E., Shin, D. H., \& Lee, M. N. (2006). Korean students' environmental Literacy and variables affecting environmental literacy. In S. Wooltorton and D. Marinova (Eds.), Sharing Wisdom for Our Future: Environmental Education in Action. Proceedings of the 2006 Conference of the Australian Association for Environmental Education.

Diaz, M. O. (2006). Middle school students science curiosity on both sides of the el paso/Juarez border. Master Abstracts International, 44(5).

Dinçol Özgür, S., \& Yılmaz, A. (2013). The effect of environmental education on the pre-service teachers' affective tendency towards the environment and cognitive structure. Procedia-Social and Behavioral Sciences, 106, 2704-2713. https://doi.org/10.1016/j.sbspro.2013.12.311

Disinger, J. F., \& Roth, C. E. (1992). Environmental literacy. Columbus, Ohio: ERIC/SMEAC Information Reference Center. ED 351201.

Driscoll, E. A. (2004). Fostering wonder and curiosity: immersion field trips in the Michigan 4-H children's garden. Master Abstracts International, 43(2), 386.

Erickson, M. F. (2008). The children and nature network-Ensuring that all children can spend quality time outdoors. Retrieved from http://www.naeyc.org/files/yc/file/200801/BTJNatureErickson.pdf

Fields, D. A. (2009). What do students gain from a week at science camp? Youth perceptions and the design of an 1mmersive. Research-Oriented Astronomy Camp. International Journal of Science Education, 31(2), 151-171. https://doi.org/10.1080/09500690701648291

Genc, M., Genc, T., \& Rasgele, P. G. (2018). Effects of nature-based environmental education on the attitudes of 7th grade students towards the environment and living organisms and affective tendency. International Research in Geographical and Environmental Education, 326-340. https://doi.org/10.1080/10382046.2017.1382211

Guisasola, J., Morentin, M., \& Zuza, K. (2005). School visits to science museums and learning sciences: a complex relationship. Physics Education, 40(6), 544. https://doi.org/10.1088/0031-9120/40/6/006

Harty, H., \& Beall, D. (1984). Toward the development of a children's science curiosity measure. Journal of Research in Science Teaching, 21(4), 425-436. https://doi.org/10.1002/tea.3660210410

Harty, H., Beall, D., \& Scharmann, L. (1985). Relationships between elementary school students' science achievement and their attitudes toward science, interest in science, reactive curiosity, and scholastic aptitude. School Science and Mathematics, 85(6), 472-479. https://doi.org/10.1111/j.1949-8594.1985.tb09650.x 
Hungerford. H. R., \& Tomera, A. N. (1977). Science in the elementary school. Champaign. IL: Stipes Publishing Company.

Krapp, A., \& Prenzel, M. (2011). Research on interest in science: Theories, methods, and findings. International Journal of Science Education, 33(1), 27-50. https://doi.org/10.1080/09500693.2010.518645

Little, H., \& Wyver, S. (2008). Outdoor play: Does avoiding the risks reduce benefits? Australian Journal of Early Childhood, 33(2), 33-40. https://doi.org/10.1177/183693910803300206

Louv, R. (2008). Last child in the woods: Saving our children from nature-deficit disorder. New York, NY: Algonquin Books.

Makki, M. H., A. E. Khalick, F., \& Boujaoude, S. (2003). Lebanese secondary school students' environmental knowledge and attitudes. Environmental Education Research, 9(1), 21-33. https://doi.org/10.1080/13504620303468

McBeth, B., \& Volk, T. (2010). The national environmental literacy project: A Baseline Study of Middle Grade Students in the United States. University of Wisconsin-Platteville, Platteville, Wisconsin, USA Southern Illinois University-Carbondale, Carbondale, Illinois, USA.

Meuth, A. M. (2010). Environmental literacy of hispanic, urban, middle school students in houston. Texas Ed. D., University of Houston.

Oweini, A., \& Houri, A. (2006). Factors affecting environmental knowledge and attitudes among Lebanese college students. Applied Environmental Education and Communication, 5(2), 95-105. https://doi.org/10.1080/15330150600648945

Öztürk, M., \& Özçelik, H. (1991). Doğu Anadolu'nun Faydalı Bitkileri. Siirt: İlim, Spor, Kültür ve Arastırma Vakfi.

Patrick, P., \& Tunnicliffe, S. D. (2011). What plants and animals do early childhood and primary students'name? Where do they see them? Journal of Science Education and Technology, 20, 630-642. https://doi.org/10.1007/s10956-011-9290-7

Poortinga, W., Steg, L., \& Vlek, C. (2004). Values, environmental concern and environmental behavior. Environment and Behavior, 36(1), 70-93. https://doi.org/10.1177/0013916503251466

Şat, B. (2006). Doğa koruma ve çevre eğitimi açısından arboretumların işlevleri ve Atatürk Arboretumu. Journal of the Faculty of Forestry Istanbul University (JFFIU), 56(2), 253-270.

Saya, Ö., Ertekin, A. S., Özen, H. Ç., Hoşgören, H., Toker, Z., \& Aksal, M. (2000). GAP Yöresindeki Endemik ve Tibbi Bitkiler. Environment Foundation of Turkey and UNDP Global Environmental Facility, Ankara.

Serin, G. (2010). İlköğretim 7. sınıf öğrencilerin fene karşı meraklarının incelenmesi/Investigation of 7th grade elementary students' science curiosity. Mustafa Kemal Üniversitesi Sosyal Bilimler Enstitüsü Dergisi, 7(13), 237-252. https://doi.org/10.14520/adyusbd.398385

Silvia, P. J. (2008). Interest-The curious emotion. Current Directions in Psychological Science, 17(1), 57-60. https://doi.org/10.1111/j.1467-8721.2008.00548.x

Smith, E. F., Steel, G., \& Gidlow, B. (2010). The temporary community: Student experiences of school-based outdoor education programmes. Journal of Experiential Education, 33(2), 136-150. https://doi.org/10.5193/jee33.2.136

Sontay, G., Gökdere, M., \& Usta, E. (2014). The Study of Scale Developing Related To The Environmental Literacy Component on the Secondary School Level. Necatibey Faculty of Education Electronic Journal of Science and Mathematics Education, 9(1), 49-80.

Spektor-Levy, O., Baruch, Y. K., \& Mevarech, Z. (2013). Science and Scientific Curiosity in Pre-school-The teacher's point of view. International Journal of Science Education, 35(13), 2226-2253. https://doi.org/10.1080/09500693.2011.631608

Ting, K. L., \& Siew, N. M. (2014). Effects of Outdoor School Ground Lessons on Students' Science Process Skills and Scientific Curiosity. Journal of Education and Learning, 3(4), 96-107. https://doi.org/10.5539/jel.v3n4p96

Worsley, A., \& Skrzypiec, G. (1998). Environmental attitudes of senior secondary school students in South Australia. Global Environmental Change, 8(3), 209-225. https://doi.org/10.1016/s0959-3780(98)00016-8 